\title{
NUMERICAL ESTIMATES OF CURRENTS AND FORCES IN LINEAR TOOLS OF THE MAGNETIC-PULSE ATTRACTION OF METALS. PART 1: LOW ELECTRICAL CONDUCTANCE METALS
}

Purpose. The electrodynamics processes study in the linear tools of magnetic-pulsed attraction, the final result of which should be the physics-mathematical dependencies for the characteristics of the flowing processes, under the conditions of intensive penetration in metal of acting electromagnetic fields, as well as numerical estimates of these processes main characteristics. Methodology. To carry out research, we used the fundamental statements of the electromagnetic field theory and the mathematical simulation with help of the standard codes from the Wolfram Mathematica package. Results. The functional dependencies for the space-temporal distributions of the currents and forces excited in the linear tools of magnetic-pulsed attraction under intensive penetration of the acting electromagnetic fields through the tool's conducting construction elements are used for the numerical estimates. From the calculation results it follows that from a physical point of view, the cause of the increase in attractive forces while decreasing the operating frequencies can be considered the intensification of penetration processes of the excited fields, which leads to increasing the magnetic pressure from the outside. Thus, the transition to low operating frequencies of the exciting currents can significantly increase the efficiency of the magnetic-pulsed attraction of the sheet metals with the linear tools. Originality. It was firstly determined that from the physical point of view, the reason for the increase in attractive forces with a decrease in operating frequencies can be considered the intensification of penetration processes of the excited fields, which leads to increasing the forces of magnetic pressure on the conductors from side of their external surfaces. Practical value. A usage of the obtained results will allow creating new, more efficient linear tools of magneticpulsed attraction of the low-electrical conduction sheet metals operating under conditions of intensive penetration of the electromagnetic fields being excited. References 10, figures 9.

Key worlds: linear tool for eliminating dents in sheet conductors, intensive penetration of the field into metals with low electrical conductance, magnetic-pulse attraction of conductors with unidirectional currents.

Метою статті є проведення чисельних оцінок основних характеристик електродинамічних процесів в лінійних інструментах магнітно-імпульсного притягання провідників 3 односпрямованими струмами в умовах інтенсивного проникнення діючих електромагнітних полів в метали з низькою питомою електропровідністю. Методика. Для проведення обчислень використовувалися положсеня теорії електромагнітного поля, щзо витікають 3 рівнянь Максвелла, і стандартні математичні програми з пакета Wolfram Mathematica. Результати. 3 а допомогою аналітичних виразів розраховані амплітудно-часові залежності струмів $і$ електродинамічних зусиль в лінійних магнітно-імпульсних інструментах, дієвість яких заснована на збудженні сил взаємного притягання провідників 3 односпрямованими струмами. Вперше встановлено, що збільшення сил притягання, в першу чергу, можливо за рахунок інтенсифікації процесів проникнення полів, цо забезпечується переходом до досить низьких робочих частот збуджуючих струмів. Практична значимість. Використання отриманих результатів дозволить створювати нові більш ефективні лінійні інструменти магнітно-імпульсного притягання заданих ділянок листових металів, щяо працюють в умовах інтенсивного проникнення збуджених електромагнітних полів. Бібл. 10, рис. 9.

Ключові слова: лінійний інструмент усунення вм'ятин в листових провідниках, інтенсивне проникнення поля в метали 3 низькою питомою електропровідністю, магнітно-імпульсне притягання провідників 3 односпрямованим струмами.

Целью статьи является проведение численных оценок основных характеристик электродинамических процессов в линейных инструментах магнитно-импульсного притяэсения проводников с однонаправленными токами в условиях интенсивного проникновения действующих электромагнитных полей в металль с низкой удельной электропроводностью. Методика. Для проведения вычислений использовались положения теории электромагнитного поля, вытекающие из уравнений Максвелла, и стандартные математические программы из пакета "Wolfram Mathematica». Результаты. С помоцью аналитических выражсений рассчитаны амплитудновременные зависимости токов и электродинамических усилий в линейных магнитно-импульсных инструментах, действенность которых основана на возбуждении сил взаимного притяжения проводников с однонаправленными токами. Виервые установлено, что увеличение сил притяжения, в первую очередь, возможсно за счет интенсификации процессов проникновения полей, что обеспечивается переходом к достаточно низким рабочим частотам возбуждающих токов. Практическая значимость. Использование полученных результатов позволит создавать новые более эффективные линейные инструменты магнитно-импульсного притяжения заданных участков листовых металлов, работающие в условиях интенсивного проникновения возбуждаемых электромагнитных полей. Библ. 10, рис. 9.

Ключевые слова: линейный инструмент устранения вмятин в листовых проводниках, интенсивное проникновение поля в металлы с низкой удельной электропроводностью, магнитно-импульсное притяжение проводников с однонаправленными токами.

Introduction. The methods of attraction of specified sections of sheet metals using the energy of pulsed magnetic fields for various kinds of processing technologies are becoming increasingly relevant in various industries [1-3]. Particular attention is paid to the development of technologies for removing dents and leveling sheet metal surfaces during the restoration of aircraft and care bodies [4].

(c) Yu.V. Batygin, E.A. Chaplygin, S.A. Shinderuk, V.A. Strelnikova 
As practice shows, more than $50 \%$ of damages are dents in areas with difficult or completely closed reverse access [4]. In this regard, a very attractive method of magnetic-pulse attraction of thin-walled sheet metals, which can be the basis for creating an effective tool for external straightening of car bodies, is the attraction by linear tools. The physical essence of this method consists in the force interaction of unidirectional parallel currents (Ampere law [10]). The first is the current in the main current lead of a linear instrument (an analog of an inductor, in the generally accepted terminology [1]). The second is the current in the metal being processed. Both currents are excited by direct serial or parallel point connection to a power source. The main conductor is the linear tool firmly fixed. The metal being processed is deformed by attraction. An obvious obstacle to the effective excitation of electrodynamic forces can be induction effects, respectively to which the current in the main current lead induces a countercurrent in the sheet workpiece, and the current in its metal induces a countercurrent in the main current lead of a linear tool.

In general, the attractiveness of this method is due to the simplicity of technical implementation and fairly high energy performance $[5,6]$. An analysis of electrodynamic processes in such a scheme will establish the requirements, the fulfillment of which will provide not only ability, but also the effectiveness of the tool of the proposed principle of action.

In fairness, it should be noted that a similar problem has already been considered previously by the authors $[7,8]$. However, the direct use of the obtained formulas and relations obtained in the cited works for practical calculations is not possible, due to the limited results found by the conditions for the formulation and solution of this problem.

The goal of the work is an analysis of the temporal characteristics of electrodynamic processes in linear instruments of magnetic-pulse attraction of sheet metals, the final result of which should be physical and mathematical dependencies for the excited currents and forces under conditions of intensive penetration of electromagnetic fields into the conducting elements of tools.

Physico-mathematical model, assumptions and problem definition. For the analysis of electromagnetic processes in the considered metal processing scheme, we adopt a calculation model (Fig. 1) corresponding to the cross section of the studied electromagnetic system with currents $J_{1}$ and $J_{2}$ [9].

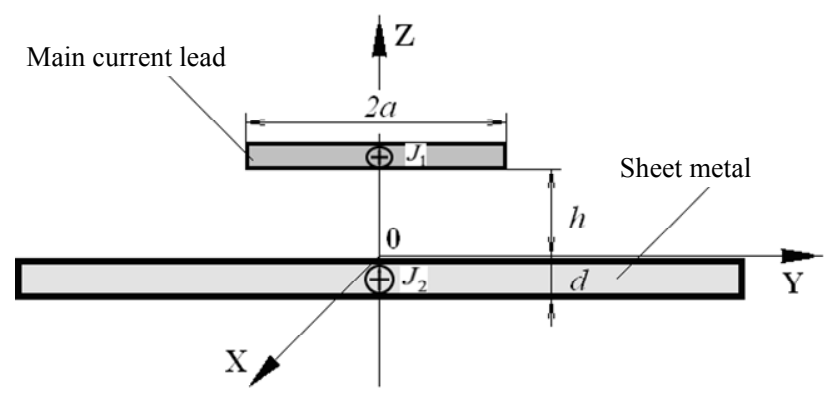

Fig 1. Calculation models ( $J_{1,2}-$ flowing currents $)$
The workpiece being processed is a rather thin sheet metal of thickness $d$ with rather large transverse dimensions and electrical conductance of the material $\gamma$.

The main current lead is also «transparent» to the existing fields, so that its metal does not affect the flowing electromagnetic processes. There is a geometric symmetry of the system relative to the ZOX coordinate plane. Along the abscissa axis OX, the system has a sufficiently large extent, so that the differentiation operator $\partial / \partial x=0$. In the main current lead in the direction of the OX axis, an exciting current uniformly distributed along OY with linear density $j(t)=j_{\mathrm{m}} \cdot j_{t}(t)$ flows, where $j_{\mathrm{m}} \cdot=I_{\mathrm{m}} / 2 a$ is the amplitude of the current density $\left(I_{\mathrm{m}}\right.$ is the maximum of the current), and $j_{t}(t)$ is the time dependence of the current.

The frequency characteristics of the exciting current are such that the condition of quasistationarity according to Landau $-\frac{\omega}{c} \cdot b<<1 \quad[10]$, where $\omega$ is the cyclic frequency of the process; $c$ is the speed of light in vacuum; $b$ is the arbitrary characteristic size of the considered electromagnetic system. Let an electromagnetic field with nonzero strength components $E_{x} \neq 0 ; H_{y, z} \neq 0$ be excited in the system. It is required to estimate the currents and forces in the electromagnetic system under consideration.

Calculation relations. For further calculations, we use the analytical expressions obtained by the authors of [9]. According to the cited publication, on the assumption that the main current lead and the given section of the deformed metal are parallel, the excited currents taking into account induction effects can be described by the following relationship. Total current in the main lead:

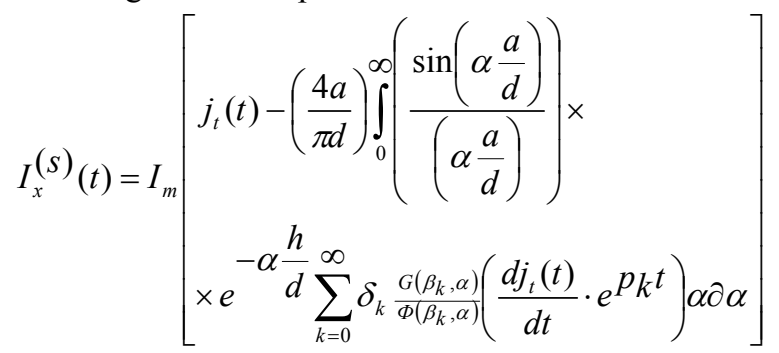

where

$$
\begin{gathered}
G\left(\beta_{k}, \alpha\right)=\left[\left(1-\cos \beta_{k}\right)+\left(\frac{\beta_{k}}{\alpha}\right)\right] \cdot \sin \beta_{k} ; \\
\Phi\left(\beta_{k}, \alpha\right)=\cos \beta_{k} \cdot\left\lfloor\alpha^{2}+2 \alpha-\beta_{k}^{2}\right\rfloor+2 \beta_{k} \sin \beta_{k} \cdot[\alpha+1] ;
\end{gathered}
$$

$\delta_{k}$ is the Kronecker symbol; $\beta_{k}$ are the roots of the equation:

$$
\operatorname{ctg} \beta_{k}=0,5 \cdot\left(\frac{\beta_{k}}{\alpha}-\frac{\alpha}{\beta_{k}}\right) ; p_{k}=-\frac{1}{\left(\mu_{0} \gamma d^{2}\right)} \cdot\left(\beta_{k}^{2}+\alpha^{2}\right),
$$

$k=0, \pm 1,2 \ldots ;\left(\frac{d j_{t}(t)}{d t} \cdot e^{p_{k} t}\right)$ is the convolution of functions.

The integral force of attraction, excited by the interaction of identical unidirectional parallel currents for the same conductors - the main current lead and the given section of sheet metal, is written in the form [5]: 


$$
F_{\text {attr }}(t)=\frac{\mu_{0}}{2 \pi} \cdot\left(I_{x}^{(s)}(t)\right)^{2} \frac{l}{h},
$$

where $\mu_{0}$ is the magnetic constant; $l$ is the conductor length; $h$ is the distance between the main current lead and sheet metal.

We carry out numerical estimates for the following initial data. Sheet metal $-d=0.001 \mathrm{~m}, \gamma=0.4 \cdot 10^{7}(\Omega \cdot \mathrm{M})^{-1}$ (steel). The main current lead is made of the same metal and the same thickness as the object being processed (the electrodynamic system "steel -steel» is considered). The geometry of the system is $l=0.06 \mathrm{~mm}, 2 a=0.01 \ldots 0.06 \mathrm{~m}$, $h=0.002 \mathrm{~m}$, the working area of the tool is the region $l \times(2 a)$. The main current lead and the given section of the metal being processed are parallel and identical, so that the currents flowing in the circuit of each of them are the same.

The parameters of current pulses are determined by the characteristics of the power source - magnetic pulse installation МИУС-2 [2], developed and created at the Laboratory of Electromagnetic Technologies of Kharkiv National Automobile and Highway University.

The maximum voltage at the capacitive storage is $U=2000 \mathrm{~V}$. The maximum operating frequency when connected directly to the МИУC-2 electrical output is $f_{\max }=7000 \mathrm{~Hz}$ (relative attenuation coefficient is $\delta / \omega=$ $=0.3$ ). The operating frequency in the discharge circuit of the installation is $f_{p}=1000 \ldots 1500 \mathrm{~Hz}$ (relative attenuation coefficient is $\delta / \omega=0.3$ ) when it is connected through a matching device with a coefficient of energy transfer to the instrument working area $K \approx 4$. Magneticpulse installation МИУС-2 allows to operate in 2 modes. The first mode is the generation of exponentially decaying (oscillating) current pulses. The second mode is the generation of current pulses of an aperiodic (unipolar) time shape. It should be noted that the latter mode is more preferable for practice, since the operation of thyristor switches of this installation with unipolar signals is characterized by a longer term of their operation.

The calculations were carried out using the standard Wolfram Mathematica software package. The approximate interval of variation of the integration variable $\alpha \in\left[0 ; \alpha_{\max }\right]$ is determined by the functional form of the Fourier image of the transverse distribution of the exciting current. For values $\alpha \in\left[0 ; \alpha_{\max }\right]$ the modulus of the distribution function must be nonzero. As shown by numerical estimates for the maximum $\alpha \in[0 ; 1]$. In the general case, the calculated dependence $\beta_{k}=\beta_{k}(\alpha)$ can be approximated by the totality of the sequence of linear functions. Numerical estimates showed that for the adopted geometry of the main current lead (inductor), the approximation of $\beta_{k}(\alpha)$ by the analytical dependence $\beta_{k} \approx \sqrt{2 \alpha}+k \cdot \pi, k=0, \pm 1, \pm 2 \ldots$ seems to be quite satisfactory. The found dependence $\beta_{k}=\beta_{k}(\alpha)$ is substituted into the integrand expression of the dependence (1).

The improper integrals and the sums of the series in them are calculated using the standard NIntegrate and NSum programs. Summation in rows is performed for different numbers of higher harmonics. Their number taken into account is considered sufficient if an increase in the limiting value of «k» per unit does not lead to a result different from the previous one by more than $5 \ldots 10 \%$. Correction of the integration interval $\alpha \in\left[0 ; \alpha_{\max }\right]$ is made for the condition $\alpha<\alpha_{\max }$ accepted a priori by comparing the final results of the calculations. Their discrepancy is allowed $\sim 5 \ldots 10 \%$.

The graphs of the characteristic calculated dependencies are grouped below by the type of current pulses generated by the magnetic pulse installation.

Graphic illustrations. In accordance with the capabilities of the power source in terms of generating current signals of various time shapes, numerical estimates of the parameters under consideration were performed initially for oscillating current pulses (Fig. 2-5).

Option No. 1. Operating frequency is $f=7000 \mathrm{~Hz}$, voltage is $U=2000 \mathrm{~V}$, working area: $l \times(2 a)=0.06 \mathrm{~m} \times 0.06 \mathrm{~m}$.

From the results of calculations for high operating frequencies $(f=7000 \mathrm{~Hz})$ it follows that in the mode of oscillating pulses of the exciting current, the maximum potential of the power source corresponds to a maximum of the attractive force of $\sim 1000 \mathrm{~N}$. The transition to the unipolar pulse of the exciting current leads to a decrease in the amplitude of the attractive force by almost $\sim 2$ times, i.e. up to $\sim 500 \mathrm{~N}$.

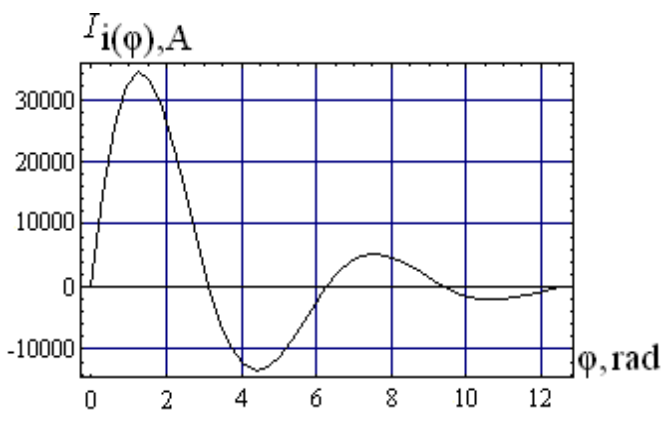

Fig. 2. Exciting current

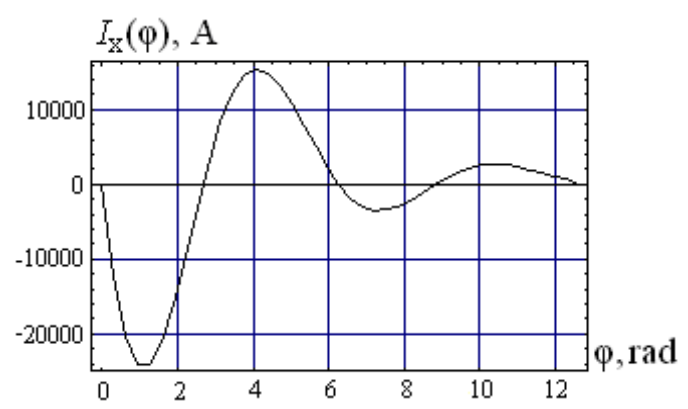

Fig. 3. Induced current

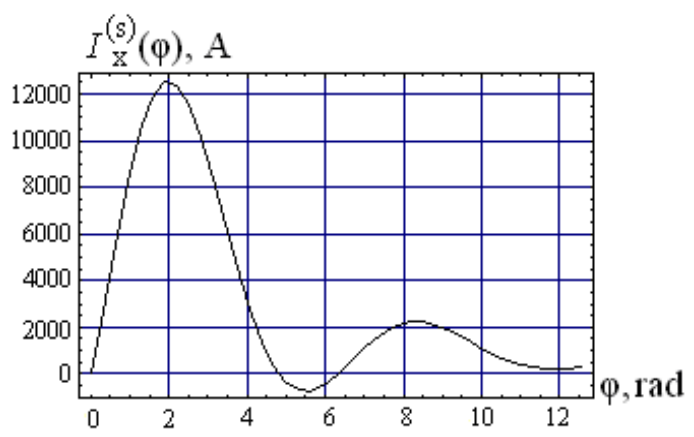

Fig. 4. Total current in the circuit of each of the interacting conductors 


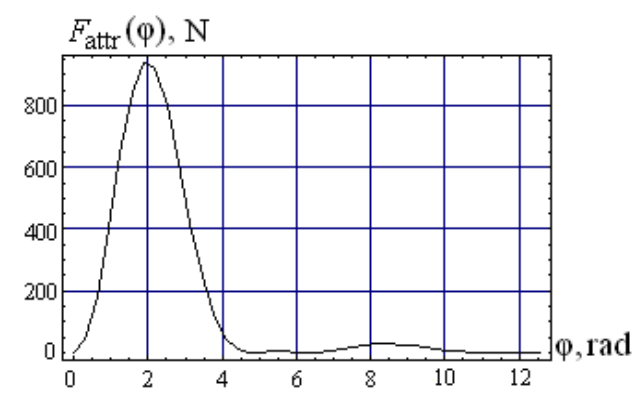

Fig. 5. Excited attractive force

From a physical point of view, as the reason for a decrease in the attractive force with an aperiodic shape of the exciting current, a decrease in its temporal duration in comparison with an oscillating and exponentially decaying harmonic signal can be considered (see Fig. 2, where $\varphi \in[0,(4 \cdot \pi)])$. This, obviously, leads to a reduction in the development time of electrodynamic processes in the processed object. All further calculations were performed for the unipolar shape of the exciting current, as more preferable for practice (increase in the operating life of the thyristor switches of the installation) (Fig. 6-9).

Option No. 2. Working frequency is $f=1500 \mathrm{~Hz}$, voltage is $U=2000 \mathrm{~V}$, working area: $l \times(2 a)=0.06 \mathrm{~m} \times$ $\times 0.06 \mathrm{~m}$.

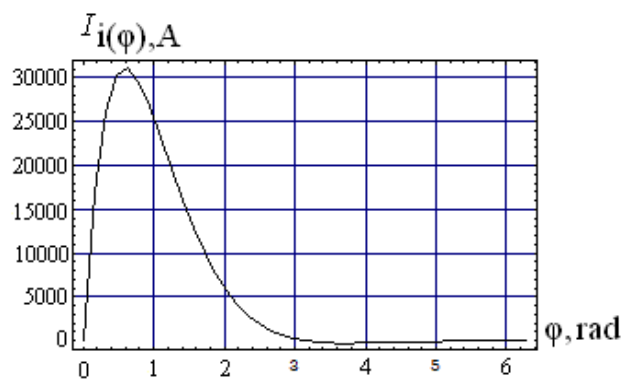

Fig. 6. Exciting current

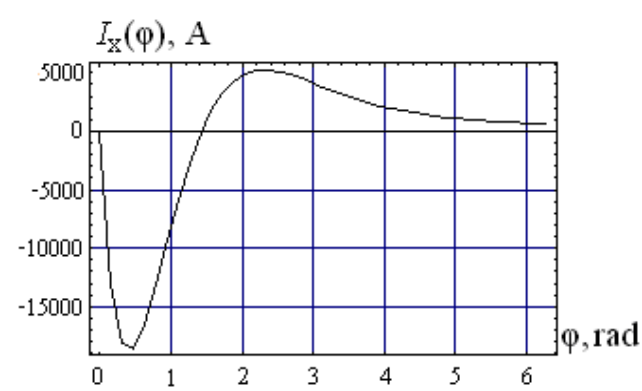

Fig. 7. Induced current

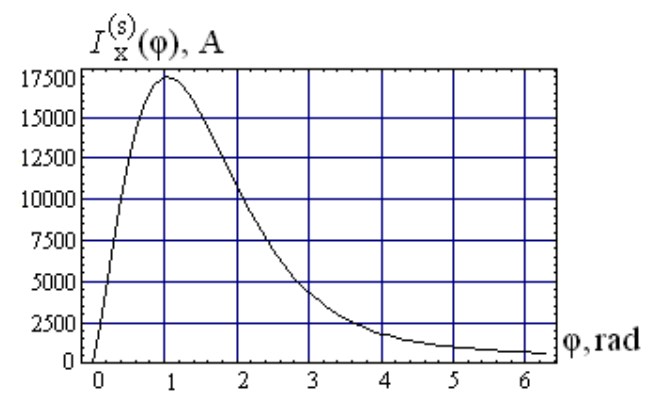

Fig. 8. Total current in the circuit of each of the interacting conductors

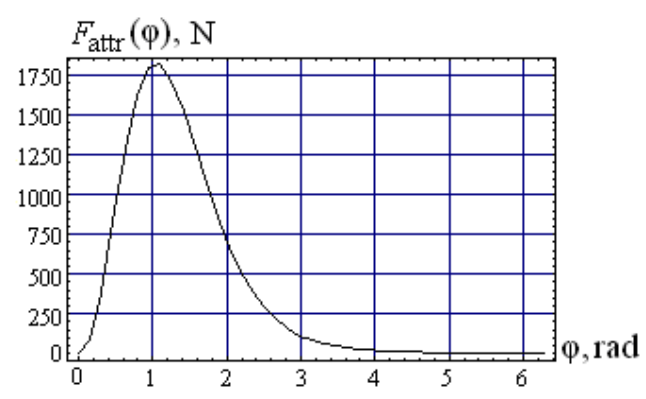

Fig. 9. Excited attractive force

From the results of calculations for low operating frequencies $(f=1500 \mathrm{~Hz})$ it follows that:

- the maximum potential of the power source corresponds to the maximum of the attractive force $\sim 1800 \mathrm{~N}$, which is approximately 2 times higher than the similar maximum for high frequencies $(f=7000 \mathrm{~Hz})$ of the exciting current;

- from a physical point of view, as the reason for the increase in attractive forces with a decrease in working frequencies, the intensification of the processes of penetration of excited fields into the workpiece metal and tool can be considered, which leads to an increase in magnetic field strengths from the outside of the system conductors and, accordingly, to an increase in magnetic pressure forces them from the outside.

\section{Conclusions.}

1. The amplitude-temporal dependencies of the characteristics of electromagnetic processes in linear instruments of magnetic-pulse attraction of sheet metals with low electrical conductance at the intense penetration of the excited magnetic fields into the conductive elements of the tools and the processed objects are calculated.

2. It has been established that the transition to low operating frequencies of exciting currents can significantly increase the amplitudes of the attractive forces of metal (for example, at $f=1.5 \mathrm{kHz}$, the force indicators for the steel being processed increase by about 2 times compared with the case when $f=7 \mathrm{kHz}$ ).

3. It is shown that as the physical reason for the increase in attractive forces with a decrease in working frequencies, the intensification of the processes of penetration of the excited fields through the metal of the tool and the workpiece can be considered, which leads to an increase in the magnetic pressure forces on the conductors from the outside.

Acknowledgment. The work was carried out by the Department of Physics of Kharkiv National Automobile and Highway University in the framework of the Research Project «Energy-saving low-cost technologies of power supply and repair of vehicles» No. 08-53-19, funded by the Ministry of Education and Science of Ukraine.

\section{REFERENCES}

1. Psyk V., Risch D., Kinsey B.L., Tekkaya A.E., Kleiner M. Electromagnetic forming - A review. Journal of Materials Processing Technology, 2011, vol.211, no.5, pp.787-829. doi: 10.1016/j.jmatprotec.2010.12.012.

2. Batygin Yu.V., Chaplygin E.A., Sabokar O.S. Magnetic pulsed processing of metals for advanced technologies of mod- 
ernity - a brief review. Electrical engineering \& electromechanics, 2016, no.5, pp. 35-39. doi: 10.20998/2074272X.2016.5.05.

3. Hnatov A., Arhun S., Ponikarovska S. Energy saving technologies for urban bus transport. International journal of automotive and mechanical engineering, 2017, vol.14, no.4, pp. 4649-4664. doi: doi:10.15282/ijame.14.4.2017.5.0366.

4. Welcome to BETAG Innovation. Available at: http://www.betaginnovation.com (accessed 17 June 2018).

5. Bondarenko A.Yu., Finkelishteyn V.B., Gavrilova T.V. External straightening basket of the motor transport by means of electro dynamic of the systems at direct drive pulsed current. Bulletin of NTU «KhPI». Series: Car- and tractorbuilding, 2014, no.9(1052), pp. 66-72. (Rus).

6. Batygin Yu.V., Chaplygin E.A., Sabokar O.S. Estimating the limit possibilities of the step charging system for capacitive energy storage. Electrical engineering \& electromechanics, 2016, no.2, pp. 35-37. doi: 10.20998/2074-272X.2016.2.06.

7. Shneerson G.A. Polja $i$ perehodnye processy $v$ apparature sil'nyh tokov. 2-e izd., pererab. $i$ dop. [Fields and transients in the equipment of strong currents. 2nd edition]. Moscow, Energoizdat Publ., 1992. 413 p. (Rus).

8. Batygin Yu.V., Chaplygin E.A., Shinderuk S.A. Calculation of fields and currents in the induction system with the attractive screen and the additional coil as a tool for the straightening. Electrical engineering \& electromechanics, 2015, no.1, pp. 5762. (Rus). doi: 10.20998/2074-272X.2015.1.11.
9. Batygin Yu.V., Yeryomina O.F., Chaplygin E.A., Strelnikova V.A. Electrodynamic processes in instruments of magnetic pulse attract at «direct current passing» through the handled metal. Bulletin of NTU «KhPI». Series: Mathematical modeling in engineering and technologies, 2019, no.8(1333), pp. 207-213. (Rus).

10. Landau L.D., Lifshits E.M. Elektrodinamika sploshnyh sred T. 8 [Continuum Electrodynamics. Vol.8]. Moscow, Fizmatlit Publ., 2005. 656 p. (Rus).

Received 16.04.2019

Yu.V. Batygin ${ }^{1}$, Doctor of Technical Science, Professor,

E.A. Chaplygin ${ }^{1}$, Candidate of Technical Science, Associate Professor.

S.A. Shinderuk ${ }^{1}$, Candidate of Technical Science, Associate Professor,

V.A. Strelnikova ${ }^{1}$, Postgraduate Student,

${ }^{1}$ Kharkiv National Automobile and Highway University, 25, Yaroslava Mudrogo Str., Kharkov, 61002, Ukraine, phone +380 577003852 ,

e-mail: yu.v.batygin@gmail.com; chaplygin.e.a@gmail.com; s.shinderuk.2016102@ukr.net; v.strelnikova91@gmail.com

How to cite this article:

Batygin Yu.V., Chaplygin E.A., Shinderuk S.A., Strelnikova V.A. Numerical estimates of currents and forces in linear tools of the magnetic-pulse attraction of metals. Part 1: Low electrical conductance metals. Electrical engineering \& electromechanics, 2019, no.5, pp. 40-44. doi: 10.20998/2074-272X.2019.5.07. 